Humanis Vol. 13 No. 1

\title{
STRATEGI KPUD LAMONGAN DALAM MENINGKATKAN PARTISIPASI PEMILIH PENYANDANG DISABILITAS DI KABUPATEN LAMONGAN PADA PEMILU SERENTAK 2019
}

\author{
Zuli Kasmawanto \\ Santi Nurjannah \\ Universitas Islam Darul 'Ulum Lamongan \\ Email: zulikasmawanto@unisda.ac.id, \\ santinurjannah@gmail.com
}

\begin{abstract}
Abstrac: Elections in Indonesia cannot be separated from voters with disabilities. Not all humans are created perfectly. Some of our brothers and sisters have to live with various deficiencies, one of which is a person with a disability (diffable / different ability). In reality, people with disabilities remain the most vulnerable group in society. One of the difficulties faced in the political field is the implementation of general elections in using their voting rights. The Lamongan KPUD needs to implement the right strategy in an effort to increase the participation of voters with disabilities. This research uses descriptive qualitative research methods. Qualitative research itself is research that as a whole makes use of interpretive methods by presenting in the form of descriptions. The results of the research obtained are that the Lamongan KPU as the election organizer has implemented a strategy to increase the participation of voters with disabilities by providing socialization and simulations regarding general elections, involving persons with disabilities by conducting a Democratic Volunteer Recrumem, some of whom are persons with disabilities.
\end{abstract}

Keywords: Lamongan KPUD Strategy, Voters with Disabilities

\begin{abstract}
Abstrak: Pemilu di Indonesia tidak lepas dengan pemilih penyandang disabilitas. Tidak semua manusia diciptakan secara sempurna ada sebagian dari saudara kita yang harus hidup dengan berbagai kekurangan salah satunya adalah penyandang disabilitas (difabel/different ability). Dalam kenyataannya penyandang disabilitas merupakan kelompok yang rentan dalam masyarakat. Salah satu kesulitan yang dihadap dalam bidang politik adalah ketika pelaksanaan pemilihan umum dalam menggunakan hak pilihnya. KPUD Lamongan perlu menerapkan strategi yang tepat dalam upaya meningkatkan partisipasi pemilih disabilitas. Penelitian ini dilakukan dengan metode penelitian kualitatif yang bersifat deskriptif. Penelitian kualitatif sendiri adalah penelitian yang secara keseluruhan memanfaatkan metode penafsiran dengan menyajikan dalam bentuk deskripsi. Hasil dari penelitian yang diperoleh adalah KPU Lamongan sebagai penyelenggara pemilu telah melakukan Strategi untuk meningkatkan partisipasi pemilih penyandang disabilitas dengan memberi sosialisasi dan simulasi mengenai tata cara pemilihan umum, melibatkan penyandang disabilitas dengan melakukan rekrutmem Relawan Demokrasi yang beberapa di antaranya adalah penyandang disabilitas.
\end{abstract}

Kata Kunci: Strategi KPUD Lamongan, Pemilih Penyandang Disabilitas 


\section{PENDAHULUAN}

Pemilu di Indonesia tidak lepas dengan pemilih penyandang disabilitas. Tidak semua manusia diciptakan secara sempurna ada sebagian dari saudara kita yang harus hidup dengan berbagai kekurangan salah satunya adalah penyandang disabilitas (difabel/different ability). Penyandang disabilitas dalam kenyataanya tetap merupakan kelompok yang paling rentan dalam masyarakat. Salah satu kesulitan yang dihadap dalam bidang politik adalah ketika pelaksanaan pemilihan umum dalam menggunakan hak pilihnya. KPUD Lamongan perlu menerapkan strategi yang tepat dalam upaya meningkatkan partisipasi pemilih disabilitas.

Berdasarkan dokumen KPU, pada tahun 2019 jumlah pemilih penyandang Tuna Grahita atau keterbelakangan mental di kabupaten Lamongan ada banyak 651 pemilih atau 0,061 persen. Tuna daksa di kabupaten lamongan, sebanyak 339 pemilih atau 0,032 tuna rungu/wicara sebanyak 237 pemilih atau 0,022 persen, tuna netra sebanyak 387 pemilih atau 0,036 persen. sementara pemilih yang tercatat sebagai disabilitas menduduki posisi paling tinggi, yakni sebanyak 732 pemilih atau 0,069 persen, angka total penyandang disabilitas 2,346 , menjadi bagian dari total pemilih 1.056.5905 di Kabupaten Lamongan dalam pemilu tahun 2019. (KPU Lamongan, www.Kpulamongankab.go.id, 9 November 2019)

KPUD Lamongan perlu menerapkan strategi yang tepat dalam upaya meningkatkan partisipasi pemilih disabilitas. Strategi yang diterapkan tersebut tentunya tidak asal dibuat, melainkan melalui berbagai pertimbangan dan riset yang mendalam mengenai kondisi penyandang disabilitas sebagai sasaran serta kondisi internal. Diharapkan penyandang disabilitas dapat menjadi lebih paham mengenai pentingnya mempergunakaan hak pilih dalam pemilu, sehingga semakin banyak penyandang disabilitas yang tertarik untuk berpartisipasi dalam pemilu. Hal ini sejalan dengan amanat undang-undang No. 22 tahun 2007 pasal 8 mengenai kewajiban, tugas dan wewenang Komisi Pemilihan Umum. Komisi Pemilihan Umum menyelenggarakan sosialisasi pemilihan umum pada masyarakat luas ini bisa dijadikan sebagai sarana pendidikan politik untuk meningkatkan pemahaman masyarakat, sosialisasi ini dampaknya terjadi pada tingkat partisipasi politik masyarakat. (UU. No 22 Tahun 2007 Pasal 8)

Salah satu indikator suksesnya suatu penyelengaraan pemilihan umum adalah partisipasi masyarakat Kabupaten yang memiliki angka tingkat partisipasi politik masyarakat dalam pemilihan umum yang cukup tinggi dan itu tidak lepas dari partisipasi pemilih penyandang disabilitas. KPU RI menargetkan 77,5\% tingkat partisipasi masyarakat di pemilu tahun
2019. KPU Kabupaten Lamongan di pemilu kali ini mencapai target nasional yaitu 78,53\% semua ini berkat kerja keras KPU dan relawan demokrasi yang selama tiga bulan gelar sosialisasi kepada masyarakat lamongan agar menggunakan pilihnya. (KPU Lamongan, www.Kpulamongankab.go.id, 9 November 2019)

Hal ini yang mendorong penulis merasa tertarik untuk meneliti hal tersebut. karena disaat wilayah lain mendapat kesulitan dalam meningkatkan partisipasi politik masyarakat, Kabupaten Lamongan masih bisa mempertahankan tingkat partisipasi politik masyarakat ini.

\section{KAJIAN PUSTAKA Strategi Politik}

Strategi menurut kamus besar Bahasa Indonesia adalah rencana yang cermat mengenai kegiatan untuk mencapai sasaran khusus. Penyusunan sebuah strategi harus menggunakan metode maupun teknik-teknik tertentu sehingga kebijaksanaan yang dihasilkan akan optimal. Untuk itu diperlukan pengetahuan dan keahlian yang memadai dalam mencapai tujuan organisasi. Strategi dalam suatu organisasi adalah tindakan-tindakan dan pendekatan-pendekatan organisasi yang diterapkan oleh pihak pimipinan guna mencapai kinerja keorganisasian yang sudah ditetapkan sebelumnya.

Macam-Macam Strategi Menurut Koteen dalam Salusu, terdapat beberapa tipe strategi yaitu sebagai berikut :

1. Strategi Organisasi (Corporate Strategy)

Strategi ini ada kaitannya dengan perumusan misi, tujuan, nilai-nilai dan inisiatif-inisiatif strategis yang baru. Pembahasan ini diperlukan, yaitu apa yang diakukan dan dilakukan untuk siapa.

2. Strategi Program (Program Strategy)

Strategi ini memberikan perhatian pada keterkaitan strategi dari suatu program tertentu yaitu dampak apabila suatu program tertentu diperkenalkan dan dilancarkan dan dampak bagi sasaran organisasi. (Annisa Putri, 2019: 55)

3. Strategi Pendukung Sumber Daya (Rescource Support Strategy) Strategi sumber daya ini dilakukan dengan memusatkan perhatian pada memaksimalkan manfaat sumber daya esensial yang telah tersedia untuk meningkatkan kualitas kinerja organisasi. Sumber daya itu berupa keuangan, tenaga, teknologi, dan lain sebagainya.

4. Strategi Kelembagaan (Institutional Strategy) Strategi kelembagaan ini focus pada pengembangan kemampuan organisasi dalam melaksanakan inisiatif-inisiatif strategis. (Salusu, 1996: 357)

\section{Partisipasi Pemilih}

Partisipasi pemilih merupakan faktor terpenting dalam suatu pengambil keputusan karena tanpa 
partisipasi pemilih keputusan yang dibuat oleh pemerintah tidak akan berjalan dengan baik. Partisipasi pemilih merupakan salah satu bagian penting dalam tatanan Negara yang demokrasi, partisipasi pemilih juga menunjukan tentang ciri khas adanya sebuah moderenisasi politik. Negara-negara yang proses moderenisasinya secara umum sudah berjalan dengan baik, biasanya tingkat partisipasinya meningkat.

Adapun tujuan partisipasi politik sebagai berikut : Pertama, parisipasi politik dilakukan agar terlibat dalam pengambilan keputusan yang dilakukan oleh pemerintah. Kedua, partisipasi politik untuk mempengaruhi dalam pengambilan keputusan pemerintah. Ketiga, tujuan dari partisipasi politik aktif, yaitu dengan cara mendatangi tempat pemungutan suara untuk mempengaruhi kebijaksanaan pemerintah.

Hak Warga untuk ikut berpartisipasi dalam pemilihan umum disebut sebagai hak pilih, yang terdiri dari hak pilih pasif (hak memilih) dan hak pilih pasif (hak dipilih).

1. Hak memilih (hak pilih aktif) Hak memilih adalah hak warga negara dalam memilih wakilnya didalam suatu pemilihan umum. Partisipasi warga Negara dalam pemilihan umum merupakan rangkaian kegiatan membuat keputusaan, yaitu apakah memilih atau tidak memilih dalam pemilihan umum. Kedaulatan politik sebuah bangsa akan tanpak dengan sendirinya di tangan rakyat pemilih melalui pemilihan umum.

2. Hak dipilih (hak pilih pasif) Hak pilih adalah hak warganegara untuk dipilih menjadi anggota sesuatu badan permusyawaratan/perwakilan rakyat dalam suatu pemilihan umum.

\section{Disitabilitas dalam Pemilu}

Kaum disabilitas adalah seseorang yang mempunyai kekurangan mental maupun fisik yang dialami dalam diri seseorang, di dalam perudangundangan kaum difabel ini dijamin haknya sebagai pemilik hak suara di pemilu sesuai dengan ketetapan yang berlaku. di Kabupaten Lamongan Penyandang Disabilitas diberikan hak untuk menggunakan hak suaranya melalui mekanisme pemilihan yang telah ditetapkan oleh KPUD Kabupaten Lamongan. (Nadya Kharima, 2014: 42) tersebut adalah :

Adapun data pemilu dari penyandang disabilitas

Tabel 1

Data Pemilu Penyandang Disabilitas 2019

\begin{tabular}{|l|l|l|}
\hline No & Kategori disitabilitas & Jumlah \\
\hline 1 & Tuna netra & 387 \\
\hline 2 & Tuna rungu & 237 \\
\hline
\end{tabular}

\begin{tabular}{|l|l|l|}
\hline 3 & Tuna grahita & 653 \\
\hline 4 & Daksa & 339 \\
\hline 5 & Lainnya & - \\
\hline Total & & 2.346 \\
\hline
\end{tabular}

\section{Disabilitas di dalam Indonesia}

Sejak awal masa kemerdekaan indonesia hingga tahun 2011, terdapat sekitar sepuluh istilah yang secara resmi digunakan dalam merujuk dan menyebutkan orang dengan sebutan disabilitas dalam interaksi sehari-hari public Indonesia ataupun dokumen legal pada tingkat nasional maupun tingkat lokal. Keterangan dari semua istilah tersebut dijabarkan adalah sebagai berikut:

a. Cacat

Istilah cacat ini pernah digunakan di dua dokumen legal yaitu Undang-undang no.33 tahun 1947 pernah menggunakan istilah cacai ini tentang Ganti Rugi Buruh yang kecelakaan, dan Undangundang No.4 tahun 1979 tentang Kesejahteraan Anak. Kedua Undang-undang tersebut sudah tidaak berlaku lagi dan digantikan dengan peraturan yang baru. Kata cacat merupakan kata benda, jika dilihat pada kamus umum bahasa Indonesia mengandung beberapa arti, yaitu: kekurangan yang menyebabkan nilai atau mutunya kurang baik atau kurang sempurna yang terdapat di badan, benda, batin atau akhlak. Lecet kerusakan yang menyebabkan keadaanya menjadi kurang baik dan kurang sempurna. Cela aib tidak kurang sempurna (Dini Widinarsih, tanpa tahun, 131).

b. Orang-orang dalam keadaan kekurangan jasmani atau rohaninya

Undang-undang no. 12 tahun 1954 tentang Dasar-dasar pendidikan dan pengajaran di sekolah untuk seluruh wilayah di Indonesia pernah menggunakan istilah ini dalam dokumen, namun Undang-undang ini sudah tidak berlaku lagi sejak terbitkannya Undang-undang no 20 tahun 2003 tentang sistem pendidikan nasional.

c. Orang yang mempunyai gangguan atau kehilangan kemampuan untuk mempertahankan hidupnya

Undang-undang no.6 tahun1974 tentang Ketentuan Pokok Kesejahteraan Sosial pernah menggunakan istilah ini dalam peraturan resmi. Undang-undang ini juga tidak berlaku lagi sejak diterbitkannya Undang-undang no. 11 tahun 2009 tentang Kesejahteraan Sosial.

d. Tuna 
Istilah tuna ini dulu pernah digunakan dalam dokumen resmi yaitu bagian penjelasan dari Undang-undang no. 6 tahun 1974 tentang ketentuan Pokok Kesejahteraan Sosial, namun undang-undang ini sudah tidak berlaku sejak digantikan peraturan baru. Jika dilihat pada Kamus Bahasa Indonesia kata "tuna" mengandung beberapa arti harfiah diantaranya yaitu luka, kurang dan tidak memiliki.

Kata tuna berasal dari bahasa Jawa kuno yang berarti rusak atau rugi. Tetapi kata ini layak digunakan pada barang yang rusak, seperti halnya kata cacat. Penggunaan kata ini dimulai pada awal tahun 1960-an sebagai bagian dari istilah yang mengacu pada kekurangan yang dialami oleh seseorang pada fungsi organ tubuhnya, penggunaan istilah tuna ini pada awalnya dimaksudkan untuk memperluas kata cacat demi untuk menghormati martabat penyandangnya.

Ragam penggunaan istilah tuna terkait dengan kekurangan fungsi organ tubuh yang dialami seseorang adalah sebagai berikut:

1) Tuna Daksa (cacat tubuh)

2) Tuna Grahita (cacat pikiran, lemah daya tangkap, keterbelakangan mental)

3) Tuna Laras (sukar mengendalikan emosi dan sosial)

4) Tuna Netra (tidak dapat melihat buta)

5) Tuna Wicara (tidak dapat berbicara bisu)

6) Tuna Rungu (tidak dapat mendengar, tuli) Uniknya walaupun dokumen sifatnya legal penggunaan istilah tuna ini sudah tidak berlaku lagi sejak diterbitkannya peraturan baru, namun istilah-istilah tersebut masih terdengar familiar.

e. Penderita Cacat

Peraturan pemerintah No. 36 Tahun 1980 tentang Usaha Kesejahteraan Sosial bagi penderita cacat pernah menggunakan istilah ini dalam dokumen. Begitu juga pada Undang-undang No. 14 Tahun 1992 tentang lalu lintas angkutan jalan. Perarturan ini sudah tidak berlaku mulai dari bergantinya Peraturan Pemerintah No. 43 Tahun 1998 tentang Usaha-usaha peningkatan Kesejahteraan Sosial bagi penyandang cacat. Serta Undang-undang No. 22 tahun 2009 tentang lalu lintas dan angkutan jalan.

f. Penyandang kelainan

Istilah ini pernah digunakan dalam dokumen Peraturan Pemerintah No. 72 Tahun 1991 tentang Pendidikan luar biasa. Serta Undang-undang No. 20 Tahun 2003 tentang Sistem Pendidikan Nasional. Undang-undang ini masih berlaku sampai saat ini sebagai peraturan resmi, kelainan yang dimaksud disini adalah mencakup kelainan fisik, mental, intelektual, emosional dan sosial. Tetapi peraturan pemerintah tersebut sudah tidak berlaku kembali sejak diterbitkanya dokumen yang baru yaitu peraturan Pemerintah no. 17 tahun 2010 tentang Pengelolaan dan penyelenggaraan pendidikan.

g. Anak berkebutuhan khusus atau biasanya disebut dengan istilah anak luar biasa

Istilah anak berkebutuhan khusus pernah digunakan dalam dokumen peraturan yang berupa surat edaran dari Direktorat Jendral Pendidikan Dasar dan menengah nomor 380/G/MN/tahun 2003 tentang pendidikan inklusi. Selain itu, istilah ini juga terdapat pada Peraturan Mentri Pemberdayaan Perempuan dan Perlindungan Anak No. 10 Tahun 2011 tentang Kebijakan Anak berkebutuhan khusus, yang kemudian sudah dicabut. (Nur Kholis, 2013, 56)

h. Penyandang Cacat

Istilah ini pertama kali digunakan dalam dokumen Undangundang No.15 Tahun 1992 tentang Penerbangan, pada Pasal 42 Undang-undang ini sudah tidak berlaku lagi sejak diterbitkanya Undangundang No. 1 Tahun 2009 tentang penerbangan. Namun seiring dengan berjalannya waktu kemudian, orang Indonesia terutama aktivis dengan disabilitas mengkritik definisi dalam Undang-undang No. 4/1997 sebagai istilah yang masih cenderung fokus atau menitikberatkan pada kekurangan fisik/physical/deficit berupa ketidak normalan secara medis. Hal ini dirasa dan dinilai mendiskreditkan, menstigma para penyandang cacat. (Arif Maftuhin, 2016: 146)

i. Difable

Sejak tahun 1990-an, di Indonesia muncul istilah difable yang merupakan singkatan dari differently abled sebagai counter terhadap penggunaan istilah penyandang cacat yang dinilai dan dirasa stigmatis. Istilah difable ini digunakan dengan argumen bahwa mereka bukan tidak mampu sebagai terjemah dari disability, melainkan memiliki kemampuan yang berbeda. Dicontohkan antara lain dengan kasus bahwa mungkin dengan tidak memiliki kaki atau kaki yang layu/lumpuh individu menjadi tidak dapat melakukan mobilitas dari satu tampat ke tempat lain dengan cara berjalan menggunakan kedua kaki (secara normal) tetapi individu tersebut tetap mampu mobilitas seperti berjalan itu dengan cara yang berbeda yaitu menggunakan kursi roda.

j. Penyandang Disabilitas

Seiring dengan Indonesia meratifikasi Konvensi PBB yang berisi tentang Hak-hak Penyandang 
Disabilitas (UNCRPD) dan tertuang menjadi Undang-undang No 19 Tahun 2011, diperkenalkan istilah penyandang disabilitas semiloka terminology "penyandang cacat" dalam rangka mendorong ratifikasi Konvensi Internasional tentang Hak-hak Pennyandang Cacat telah diadakan pada 8-9 Januari 2009, dihadiri oleh para pakar (linguistic, sosial budaya, hukum, hak asasi manusia/HAM, psikologi)

\section{METODE PENELITIAN}

1. Jenis Penelitian

Penelitian ini menggunakan desain studi dengan metode penelitian yaitu metode penelitian kualitatif. Penelitian yang menghasilkan data deskriptif melalui kata-kata tertulis atau lisan dari subjek yang diteliti.

2. Fokus Penelitian adalah :

Adapun yang menjadi fokus penelitian

a. Strategi yang dilakukan oleh KPU untuk meningkatkan partisipasi pemilih di Kabupaten Lamongan terutama bagi penyandang disabilitas pada pemilu serentak 2019.

b. Hambatan-hambatan yang dialami oleh KPU dalam meningkatkan partisipasi pemilih penyandang disabilitas di Kabupaten Lamongan pada pemilu serentak 2019.

c. Manfaat sosialisasi yang diperoleh penyandang disabilitas, dengan strategi KPU dalam meningkatkan partisipasi pemilih penyandang disabilitas.

3. Lokasi Penelitian

Lokasi penelitian merupakan alur yang paling utama dalam menangkap fenomena atau peristiwa yang sebenarnya dari objek yang diteliti dalam rangka mendapatkan data-data penelitian yang akurat. Untuk menunjang hasil data yang sesuai dalam mencapai hasil penelitian yang sesuai, maka penelitian akan dilakukan di KPU Kabupaten Lamongan dan di Komunitas Penyandang Disabilitas.

4. Informan Penelitian

Teknik penentuan informan dalam penelitian ini menggunakan teknik purposive sampling, dipenelitian kualitatif tidak dipersoalkan beberapa jumlah informan, dimana peneliti mengambil informan yang mengetahui permasalahan tentang strategi KPU dalam meningkatkan pertisipasi pemilih penyandang disabilitas. Yang ikut terjun langsung memberikan penyuluhan.

5. Sumber Informasi
Mengumpulkan data untuk penelitian kualitatif diperlukan kecermatan lebih agar memperoleh data yang diinginkan. Karena penelitian kualitatif mengandalkan perolehan data dari hasil observasi dan interaksi yang dilakukan oleh peneliti.

6. Teknik Pengumpulan

Data Dalam studi ini sumber informasi digolongkan dalam dua kategori yaitu data primer dan data skunder. Data primer merupakan data yang berasal dari sumber utama dan dikumpulkan secara khusus untuk menjawab pertanyaan penelitian. Sedangkan data skunder merupakan data yang digunakan untuk mengisi kebutuhan akan rujukan khusus pada beberapa hal. Adapun teknik pengambilan data yang digunakan dalam penelitian ini adalah: (Sugiono, 2012:224-226

a) Observasi

Teknik Observasi dalam penelitian ini dilakukan dengan cara penelitian langsung turun ke lapangan lokasi penelitian, untuk melihat dan mendengar sumber data. Adapun fokus yang akan diamati adalah di KPU Kabupaten Lamongan serta Komunitas Penyandang Disabilitas.

b) Wawancara

Teknik wawancara ini dimaksudkan untuk mengumpulkan data dangan cara Tanya jawab yang dikerjakaan dengan sistematik dan berlandaskan pada masalah, tujuan dan hipotesis penelitian. Hal ini mengenai pada laporan diri sendiri atau self-report, atau setidaknya pada pengetahuan dan atau keyakinan pribadi. Dalam penelitian ini penulis mengunakan metode (interview) yaitu Tanya jawab terarah. Wawancara adalah percakapaan dengan maksud tertentu. Percakapan dilakukan oleh dua pihak, yaitu pewawancara (interviewer) mengajukaan pertanyaan dan pewawancara (interviewee) orang yang memberikan jawaban atas pertanyaan itu. Dalam penelitiaan ini, peneliti menggunakan teknik wawancara semi terstruktur. Pengumpulan data dengan teknik wawancara ini mengharuskan pewawancara membuat garis besar pokok-pokok dan kerangka yang dirumuskan tidak perlu dipertanyakan secara berurutan. Tujuan peneliti menggunakan teknik wawancara adalah untuk mendapatkan data secara jelas serta konkret tentang bagaimana setrategi KPU untuk meningkatkan partisipasi pemilih penyandang disabilitas. Peneliti menggunakan teknik ini agar wawancara dapat 
terarah sesuai konsep dan dan untuk menjaga agar pokok-pokok yang direncanakaan dapat seluruhnya tercakup. Wawancara dilakukan berdasarkan kisi-kisi pertanyaan dan disesuaikan dengan keadaan responden dalam konteks wawancara sebenarnya. Penelitian mengunakaan wawancara semi terstruktur (indept interview) yang mana pertanyaan dikembangkan sambil bertanya setelah informan tersebut menjawab sehingga terjadi wawancara yang interaktif antara peneliti dengan informan. Wawancara dilakukan dengan direkam sehingga data yang diperoleh dapat dikonfirmasi kembali.

c) Dokumentasi

Peneliti menggunakan dokumentasi sebagai dasar untuk mengungkap masalahmasalah yang ada dalam penelitian ini. Teknik pengumpulan data dokumentasi adalah pengambilan data yang diperoleh melalui dokumendokumen, dalam penelitian ini penulis mengumpulkan data-data seperti hasil penelitian terdahulu, catatan, laporan-laporan dan foto-foto yang berkiatan dengan lokasi penelitian dan masalah yang diteliti.

d) Triangulasi

Untuk mendapatkan keabsahan hasil dari sebuah penelitian, sebelum menentukan dan memutuskan analisis data, pertama kali yang dilakukan adalah pemeriksaan keabsahan untuk mengetahui kebenaraan dan keakuratan data yang diperoleh dalam penelitian ini. Peneliti melakukan penelitian ini dengan triangulasi Metode. Menurut patton dalam Moleong, menjelaskan bahwa terdapat dua strategi yaitu, (1) pengecekan terhadap kepercayaan penemuan hasil penelitian dari beberapa pengumpulan data. (2) pengecekan derajat kepercayaan beberapa sumber data mengunakan metode yang sama. Dengan menggali kebenaraan informasi tertentu melalui berbagai metode dan sumber perolehan data. Misalnya dengan wawancara, dokumen, gambar atau foto. Dengan beberapa cara itu, peneliti akan mendapatkan pandangan yang berbeda pula mengenai fenomena yang diteliti.

7. Teknik Analisis Data

Teknik analisis data dilakukan saat pengumpulan data berlangsung, dan setelah pengumpulan data dalam priode tertentu. Pada saat wawancara, peneliti harus melakukan analisis terhadap hasil jawaban wawancara. Jika hasil jawaban yang diwawancarai dirasa belum memuaskan, maka peneliti dapat mengajukan pertanyaan lagi, sampai tahap tertentu, hingga diperoleh data yang dianggap kardibel oleh peneliti.

Analisis data penelitian kualitatif ini dilakukan secara intraktif dan berlangsung terus menerus sampai tuntas. Langkah-langkah analisis data adalah sebagai berikut:

a) Pengumpulan Data

Pengumpulan data yaitu peneliti mengumpulkan data di lokasi penelitian dengan cara observasi, wawancara, dan mendokumentasi kegiatan yang diteliti dengan menentukan strategi pengumpulan data yang dipandang tepat dan untuk menentukan fokus serta pendalaman data pada saat proses pengumpulan data.

b) Reduksi Data

Reduksi data yaitu proses pemilihan, pemusatan perhatian pada penyerderhanaan, pengabstrakan, dan transformasi data yang muncul dari catatancatatan tertulis dilapangan. Peneliti melakukan reduksi data ini dengan terus menerus dalam penelitian kualitatif. Dengan cara reduksi data, peneliti dapat memilih data yang dikode dan membuang pola mana yang tidak sesuai serta meringkas sebagian data tersebar dan cerita apa yang sedang berkembang kemudian disesuaikan dengan kebutuhan penelitian tentang relasi KPU ini.

c) Penyajiaan Data Data yang telah didapatkan dan disusun sehingga mampu untuk dibuat sebuah kesimpulan. Pada penelitian kualitatif penyajian data berupa teks naratif termasuk data yang berupa angka diuraikan dalam bentuk kata dan kalimat.

d) Penarikan kesimpulan Penarikan kesimpulan merupakan salah satu kegiatan analisis yang lebih dikhususkan pada penafsiran data yang telah disajikan.36 Selama penelitian berlangsung, kesimpulan dari penelitian ini merupakan hasil dari data yang diperoleh KPU Kabupaten Lamongan sebagai objek penelitian dan juga dari teori yang digunakan sehingga dapat menarik kesimpulan yang sesuai dengan alur penelitian.

HASIL DAN PEMBAHASAN

A. Strategi KPU Lamongan dalam Meningkatkan Partiaipasi Penyandang Disabilitas dalam Pelaksanaan Pemilihan Umum

Komisi Pemilihan Umum memiliki misi meningkatkan kesadaran politik rakyat untuk berpartisipasi aktif dalam pemilihan Umum demi terwujudtnya cita-cita masyarakat Indonesia yang demokratis. Melalui penyusunan peraturan yang aksesabel terhadap penyandang disabilitas, ruangruang yang menjadi celah minimnya akses selalu diupayakan 
untuk diperbaiki. Minimnya informasi dan fasilitas bagi penyandang disabilitas menjadi kendala utama rendahnya partisioasi dalam penyelenggaraan pemilu. Kebijakan yang bisadilakukan adalah bahwa fasilitas kertas atau surat suara itu perlu ditingkatkan. Hal ini tentu saja bisa dilakukan dengan mengacu pada jumlah data pemilih. Karena tidak semua wilayah mempunyai pemilih difabel. Dengan data akurat, maka diharapkan dari panitia bisa lebih memberikan perhatian khusus bagi kaum difabel. Untuk TPS kedepan, juga disediakan bilik khusus difabel kalau memang di TPS yang bersangkutan terhadap pemilih difabel sehingga kenyamanan kelompok difabel bisa ditingkatkan. Untuk hal ini, memang dibutuhkan kerja sama dari berbagai pihak terutama dari KPU Kabupaten Lamongan dan Dinas Sosial Kabupaten, mengingat karena sekarang dari Dinas Sosial adalah kelompok yang memberi perhatian lebih kepada kaum difabel.

Komisi Pemilihan Umum Kabupaten Lamongan diberikan tugas menyelenggarakan Pemilihan di dalam wilayah kerjanya sebagaimana dimaksud dalam undang-undang penyelenggara pemilihan umum. Untuk itu KPU Kabupaten Lamongan berupaya untuk meningkatkan peran dan partisipasi aktif masyarakat khususnya kelompok penyandang disabilitas melalui kegiatan sosialisasi. Menurut peraturan Komisi Pemilihan Umum Nomor 05 Tahun 2015 Pasal 1 angka 10, Sosialisasi Pemilihan adalah proses penyampaian informasi tentang tahapan dan program penyelenggaraan pemilihan.64 Dalam implementasinya sosialisasi diselenggarakan di seluruh wilayah kabupaten/kota dalam hal ini tentunya wilayah Kabupaten Lamongan.

Pada Pemilu serentak 2019 KPU Kabupaten Lamongan juga melakukan sosialisasi kepada Komunitas Penyandang disabilitas di Kabupaten Lamongan guna meningkatkan Partisipasi Politik. Berdasarkan analisis strategi yang diuraikan diatas, KPU Lamongan merumuskan strategi atau kebijakan yang dilakukan KPU Lamongan dalam meningkatkan peran warga penyandang disabilitas antara lain :

1. Penguatan Kelembagaan

Lebih khusus dalam bidang pemerintah berpendapat bahwa pengembangan kapasitas merupakan serangkaian strategi yang diajukan untuk meningkatkan efisiensi, efektivitas, dan responsivitas dari kinerja pemerintah, dengan memuasatkan perhatian kepada pengembangan dimensi, sumber daya manusia, penguatan organisasi dan reformasi kelembagaan atau lingkungan.

a) Meningkatkan Peran PPS dan KPPS sebagai komunikator dalam sosialisasi kegiatan pemilu
Menurut penuturan pak Siswanto diatas menyebutkan bahwa KPU Lamongan dalam penguatan kelembagaan adalah mengadakan Bimbingan Teknis dengan melibatkan anggota PPS dan KPPS, yang bertujuan setelah Bimbingan Teknis PPS dan KPPS bisa mensosialisasikan kepada masyarakat dengan cermat, berbuat adil, menjaga independensi dan professional. KPU Lamongan adalah instansi yang mempunyai wewenang penuh dalam menyelenggarakan pemilu dengan didukung Undang-undang atau peraturan yang berupa kewenangan dan tugas.

b) Pembentukan Relawan Demokrasi

Keberadaan relawan demokrasi untuk mengkampanyekan kesadaran dalam menggunakan hak pilih dirasa mampu memberi konstribusi. Walaupun kendala secara mendasar tetap ada yaitu kendala waktu, dimana masalah waktu pembentukan para relawan yang dilakukan masih terasa kurang terutama bagi kelompok difabel. Karena untuk sosialisasi kepada difabel banyak yang harus diperhatikan. Berbeda dengan segmentasi relawan demokrasi bagi stakeholder yang lain, mungkin lebih mudah. Karen mereka bisa menggunakan berbagai macam strategi pendekatan namun kalau untuk kelompok difabel, itu tidak bisa dilakukan, karena memang forumnya harus khusus. Relawan demokrasi, sejauh ini memberi dampak bagi penyandang disabilitas untuk bisa lebih kenal politik. Banyak diskusi-diskusi yang menghasilkan dinamika untuk bisa lebih jauh mengetahui bahwa kebutuhna difabel antar satu kelompok dengan kelompok yang lain tidaklah sama tetapi seringkali dipukul rata bahwa semua difabel itu sama

2. Strategi Program sosialisasi

Strategi sosialisasi KPU Lamongan yaitu berupa tatp muka denagn pola pelaksanaanya yaitu melalui ceramah, dialog, serta melakukan simulasi pencoblosan, strategi ini dipilih oleh KPU dengan maksud selain menyebarkan informasi pemilu kepada masyarakat, KPU juga ingin menjalin ikatan emosional dengan masyarakat penyandang disabilitas. Dari strategi sosialisasi yang sudah dilaksanakan oleh KPU Kabupaten Lamongan kepada segmen masyarakat disabilitas tersebut diliat dari muatan materi sosialisasi, serta strategi sosialisasi yang digunakan menunjukan sudah sesuai dengan krakteristik segmen, serta pelaksanaan sosialisasi tersebut sudah berjalan dengan peraturan yang ada. 


\section{B. Faktor Pendukung dan Penghambat}

1. Faktor Pendukung

a) Kerjasama dengan Organisasi Masyarakat

Dari untaian pembahasan yang telah diuraikan peneliti pada pembahasan sebelumnya maka terlihat bahwa peran organisasi masyarakat sangat membantu dalam proses sosialisasi, hal tersebut dapat dilihat dari kerjasama yang dilakukan KPUD Lamongan dengan lembaga swadaya masyarakat yang bergerak dibidang kaum difabel yakni sigap dan cikal yang menjembatani peran KPUD dalam memberikan sosialisasi kepada penyandang disabilitas dengan demikian tidak terjadi kendala dalam proses komunikasi yang dilakukan baik dari pihak pembicara atau narasumber yakni KPUD Lamongan dan dari pihak penyandang disabilitas selaku peserta sosialisasi.

b) Penggunaan Alat Peraga Sosialisasi (APS) Dalam sosialisasinya KPU Lamongan juga membuat alat peraga sosialisasi (APS), penggunaan APS ini tentu menjadi faktor pendukung yang dapat dirasakan langsung oleh masyarakat melalui proses sosialisasi, alat APS yang dibentuk untuk digunakan oleh KPUD Kabupaten Lamongan, ini juga mencakup semua elemen masyarakat, baik masyarakat yang normal maupun masyarakat yang mengalami disabilitas, sehingga dengan adanya APS yang dikeluarkan oleh KPUD Kabupaten Lamongan membantu pihak KPUD dalam memberikan sosialisasi guna memperlancar dan mengurangi resiko penurunan pemilih.

c) Media Massa Di era yang semakin canggih ini tentu menjadi hal yang wajar apabila pihak KPU Lamongan melakukan sosialisasi melalui media massa, karena melihat aspek-aspek yang ada dimasyarakat sehingga penggunaan media massa ini dinilai efektif dalam pelaksanaan sosialisasi. Dengan berbagai pilihan media massa seperti media tronik (yakni televisi, radio) media siber (yakni media sosial, website serta blogspot) dan media cetak (yakni surat kabar, banner) tentu akan memberikan kemudahan bagi masyarakat untuk mendapatkan berbagai informasi tentang tahapan dan sosialisasi pemilu.

d) Peran serta petugas KPUD Lamongan melalui Relasi Tidak dapat dipungkiri bahwa sukses dan tidaknya pelaksaan pemilu berasal dari proses sosialisasi, apabila proses sosialisasi ini berjalan dengan baik maka akan didapat hasil yang linear dengan proses sosialisasi begitupun sebaliknya. Dibalik kesuksesan dari proses sosialisasi yang diklaim oleh pihak KPU Lamongan tidak lepas dari peran serta relawan demokrasi (Relasi) yang menjadi gardu depan dalam proses sosialisasi, relasi inilah yang turun langsung ke lapangan untuk memberikan arahan dan sosialisasi tentang pemilu 2019 dengan masuk kedalam setiap bagian elemen masyarakat. Sehingga didalam proses yang dilakukan relasi inilah yang nantinya menjadi titik kunci keberhasilan dari proses sosialisasi.

2. Faktor Penghambat

Kendala Anggaran

Dalam menyelenggarakan sosialisasi atau programprogram dalam upaya meningkatkan partisipasi pemilih dukungan finansial atau anggaran menjadi sangat penting. Dalam hal ini kendala KPUD Kabupaten Lamongan adalah anggaran yang kurang memadai. Anggaran menjadi salah satu kendala KPUD Kabupaten Lamongan dalam menjalankan program-program terkait pemilu serentak di Kabupaten Lamongan Tahun 2019. Anggaran yang diterima KPU Lamongan sebesar Rp 25.590.000.000. Anggaran sangat dibutuhkan untuk menopang program-program dan mensukseskan pemilu seretak 2019, untuk anggaran sosialisasi, bisa dikatakan kurang Karena cakupan segmentasnya ini luas, meliputi basis disabilitas, basis keluarga, basis pemilih pemula, basis pemilih pemuda, basis kaum marjinal, basis komunitas, basis keagamaan, basis warga internet dan basis warga adat dan budaya. Ini mengakibatkan program-program KPUD Kabupaten Lamongan menjadi terhambat. Untuk melaksanakan program dari KPU jelas memakan biaya, dan keterbatasan biaya yang dimiliki KPU Kabupaten Lamongan menjadi penghambat misalnya 70 sosialisasi terhadap masyarakat, biaya untuk perlengkapan seperti kertas, tinta dan transportasi memakan biaya yang cukup besar sedangkan biaya yang dimiliki KPU Kabupaten di Lamongan sangat minim

\section{SIMPULAN DAN SARAN}

A. Simpulan

1. Strategi KPU dalam meningkatkan partisipasi pemilih penyandang disabilitas yaitu dengan cara Penguatan Kelembagaan meningkatkan peran PPK, PPS, dan KPPS sebagai komunikator dalam sosialisasi kegiatan pemilu, pembentukan relawan demokrasi dalam kapasitasnya untuk membantu kerja-kerja sosialisasi dalam rangka promosi penggunaan hak pilih bagi warga khusunya penyandang disabilitas, setidaknya memberi dampak secara tidak langsung bagi upaya meningkatkan partisipasi pemilih penyandang 
disabilitas dalam pemilu serentak 2019. Strategi Program sosialisasi komunikasi dengan tatap muka secara langsung tanpa perantara. Menyampaikan informasi tentang tahapan, jadwal, dan program pemilihan, kemudian memberikan pemahaman dan kesadaran kepada masyarakat disabilitas tentang pentingnya partisipasi masyarakat disabilitas dalam mendukung terlaksananya pemilu serentak 2019 dikabupaten lamongan. Komunikasi melalui media massa adanya penggunaan berbagai media komunikasi, media siber yang digunakan KPU Kabupaten Lamongan dalam mensosialisasikan pelaksanaan pemilihan umum, merupakan hal yang penting dalam meningkatkan pertisipasi masyarakat.

2. Faktor Pendukung dan Penghambat Faktor pendukung berkerjasama dengan Organisasi Masyarakat, peran organisasi masyarakat sangat membantu dalam proses sosialisasi, hal tersebut dapat dilihat dari kerjasama yang dilakukan KPUD Lamongan dengan lembaga swadaya masyarakat yang bergerak dibidang kaum difable. penggunaan APS menjadi faktor pendukung yang dapat dirasakan langsung oleh masyarakat melalui proses sosialisasi, alat APS yang dibentuk untuk digunakan oleh KPUD Kabupaten Lamongan, ini juga mencakup semua elemen masyarakat, baik masyarakat yang normal maupun masyarakat yang mengalami disabilitas. Komunikasi melalui Media massa siber memberikan kemudahan bagi masyarakat untuk mendapatkan berbagai informasi tentang tahapan dan sosialisasi pemilu. Yang menjadi Faktor Penghambat KPU Lamongan yaitu keterbatasan biaya yang dimiliki KPU Kabupaten Lamongan menjadi penghambat misalnya sosialisasi terhadap masyarakat, biaya untuk perlengkapan seperti kertas, tinta dan transportasi memakan biaya yang cukup besar sedangkan biaya yang dimiliki KPU Kabupaten di Lamongan sangat minim.

B. Saran

1. Hendaknya pihak KPU Kabupaten Lamongan melakukan usaha-usaha peningkatan kemampuan anggotanya secara kuantitas dan kualitas sehingga mampu bertindak efektif dan efesien guna mengantisipasi berbagai macam kendala yang sering terjadi pada tingkat teknis lapangan.

2. Hendaknya secara rutin KPU Kabupaten Lamongan selalu mensosialisasikan kegiatan yang berkaitan dengan pemilu, tidak hanya dilakukan pada saat pemilu akan dilasanakan, khususnya mengadakan Komunikasi dengan komunitas disabilitas terkait penambahan data difabel dan selanjutnya didata untuk dilakukan sosialisasi dan menambah alat bantu yang dibutuhkan, terkhusus untuk didesa yang banyak masyarakat penyandang difabelnya.

3. KPU harus lebih giat lagi menggandeng organisasi kemasyarakatan maupun Komunitas yang ada di Kabupaten Lamongan guna mensukseskan pemilu terdekat ini (PILBUP), agar semua kalangan paham akan pentingnya hak pilih mereka

\section{DAFTAR PUSTAKA}

Annisa Putri, Strategi Komisi Pemilihan Umum Kota Bandar Lampung Dalam Peningkatan Partisipasi pemilih Pemula Pada Pilpres 2019,

Dini Widinarsih, "Perkembangan Istilah dan definisi" dalam Jurnal Ilmu Kesejahteraan sosial, Vol. I, No. 2 Oktober

Kamus Besar Bahasa Indonesia, (Depertemen Pendidikan Nasional Edisi ke-3 Balai Pustaka, Jakarta Grenmedia, 2000)

Miriam budiardjo. Dasar-Dasar ilmu politik. (Jakarta: PT Gramedia Pustaka Utama,2012)

Nadya Kharima, Problematika Penyandang Disabilitas dalam Pemilu Studi Kasus Pemilu Legislatif tahun 2014 di Jakarta Dalam Jurnal Penyandang Disabilitas Pemilu, aksebilitas. hal. 42. Vol 5. N0. 1 juni 2016.

Nur Kholis, Panduan Anak Berkebutuhan Khusus. (Yogyakarta : Imperium, 2013)

Onong Uchjana Effendy, Ilmu Komunikasi Teori dan Praktek, (Bandung: PT Remaja Rosdakarya, 2001)

Salusu, Pengambilan Keputusan Stratejik untuk Organisasi Publik dan Organisasi Nonprofit. (Gransindo, Jakarta, 1996)

Sugiyono. 2012. Metode Penelitian Kualitatif Kuantitatif dan R \& D. Bandung: Alfabeta.

Winardi, Enterpreneur dan Enterpreneurship. (Jakarta: CV. Kencana, 2003)

Arif Maftuhin, "Meningkatkan Diskriminasi Penyandang

Cacat, Difabel, dan Penyandang Disabilitas" dalam Jurnal Inklusi Disability Sudies, Vol. 3, No. 2, JuliDesember 2016

Data KPU Lamongan. www.Kpu-lamongankab.go.id, Diakses minggu. 9/11/2019. 